\title{
Would the Dream of Political Equality Turn out to Be a Nightmare?
}

\section{Citation}

Verba, Sidney. 2003. Would the dream of political equality turn out to be a nightmare?

Perspectives on Politics 1, no. 4: 663-679.

\section{Published Version}

http://dx.doi.org/10.1017/S1537592703000458

\section{Permanent link}

http://nrs.harvard.edu/urn-3:HUL.InstRepos:2640591

\section{Terms of Use}

This article was downloaded from Harvard University's DASH repository, and is made available under the terms and conditions applicable to Other Posted Material, as set forth at http:// nrs.harvard.edu/urn-3:HUL.InstRepos:dash.current.terms-of-use\#LAA

\section{Share Your Story}

The Harvard community has made this article openly available.

Please share how this access benefits you. Submit a story.

\section{Accessibility}




\title{
Would the Dream of Political Equality Turn out to Be a Nightmare?
}

By Sidney Verba

\begin{abstract}
Studies of citizen participation often assume that widespread and equal participation is beneficial for democracy. This article examines the arguments for and against equal citizen participation: although it may lead to lower-quality participation-less informed, less supportive of democracy-it also leads to a distortion of the needs and preferences of citizens as they are communicated into the political process.
\end{abstract}

Observing some beggars in the street as we walked along, I said to him I supposed that there was no country in the world in which the misery of want in the lowest classes of the people was prevented. Johnson [replied]: "I believe, sir, there is not, but it is better that some should be unhappy than that none should be happy, which would be the case in a general state of equality." - James Boswell, Life of Johnson

We may naturally believe that it is not the prosperity of the few, but the greater well-being of all that is most pleasing in the sight of the Creator. . . . A state of equality is perhaps less elevated, but it is more just, and its justice constitutes its greatness and its beauty.

- Alexis de Tocqueville, Democracy in America

Je participe

Tu participes

Il participe

Nous participons

Vous participez

Ils profitent

— From a Wall in Paris, $1972^{1}$

O

$\mathrm{f}$ the various ways in which U.S. citizens can be unequal, political inequality is one of the most significant and troubling. Political equality refers to the extent to which citizens have an equal voice in governmental decisions. One of the bedrock principles in a democracy is the equal consideration of the preferences and interests of all citizens. This is expressed in such concepts as one person/one vote, equality before the law, and equal rights of free speech. It is fostered by equal political activity among citizens-not only in voting turnout across significant categories of citizens, but also in other forms of participation, ${ }^{3}$ including work in a political campaign, campaign contributions, various sorts of civic activity within one's local community, direct contact with officials, and protest. Equal activity is crucial for equal consideration since political activity is the means by which citizens make their needs and preferences known to governing elites and induce them to be responsive. Citizen participation is, thus, at the heart of political equality. Through their activity, cit-

Sidney Verba is Carl H. Pforzheimer University Professor at Harvard University and director of the Harvard University Library (sverba@harvard.edu). He gratefully acknowledges input from several individuals. ${ }^{2}$ izens in a democracy seek to control who will hold public office and to influence what the government does.

Equality in all domains of social and political life is complex. It can be about many different valued goods (income, education, health); it can be across individuals or groups; it can be calculated with different measures and on the basis of different criteria. There are, as the title of the book Equalities (by Douglas Rae and his colleagues) ${ }^{4}$ makes clear, many versions of it. And in most of its forms, it is something of mixed worth. For most valued things-income or education or health or respect or political influence-gross inequalities are something we dislike. But complete equality is rarely unambiguously desirable. It is usually impossible to attain, or the process of attaining it would be too costly, or its consequences would be negative. It may, therefore, be useful to consider why political equalitydefined roughly as equal influence over government policy across citizens-might be desirable within the framework of democratic governance, but also why the cost of such equality might be too great.

This article responds to the new and important mission of Perspectives on Politics to reach beyond the standard research article. I present very little new research here; rather, I offer an overview of some significant issues in the study of citizen 
activity and its relation to political equality. The topic is broad, and much has been written on it. To give this article some boundaries as well as some coherence, I will not attempt a summary or overview of the empirical research on the subject-except in the most cursory way, to set the stage for what I want to discuss. ${ }^{5}$ I will instead focus on broader issues that frame the questions associated with citizen activity, in particular some normative questions on participatory equality: for example, how much of what kind of participation from whom is desirable? The normative discussion will be informed by the data on citizen activity, bridging a divide that sometimes exists in the discourse on political equality

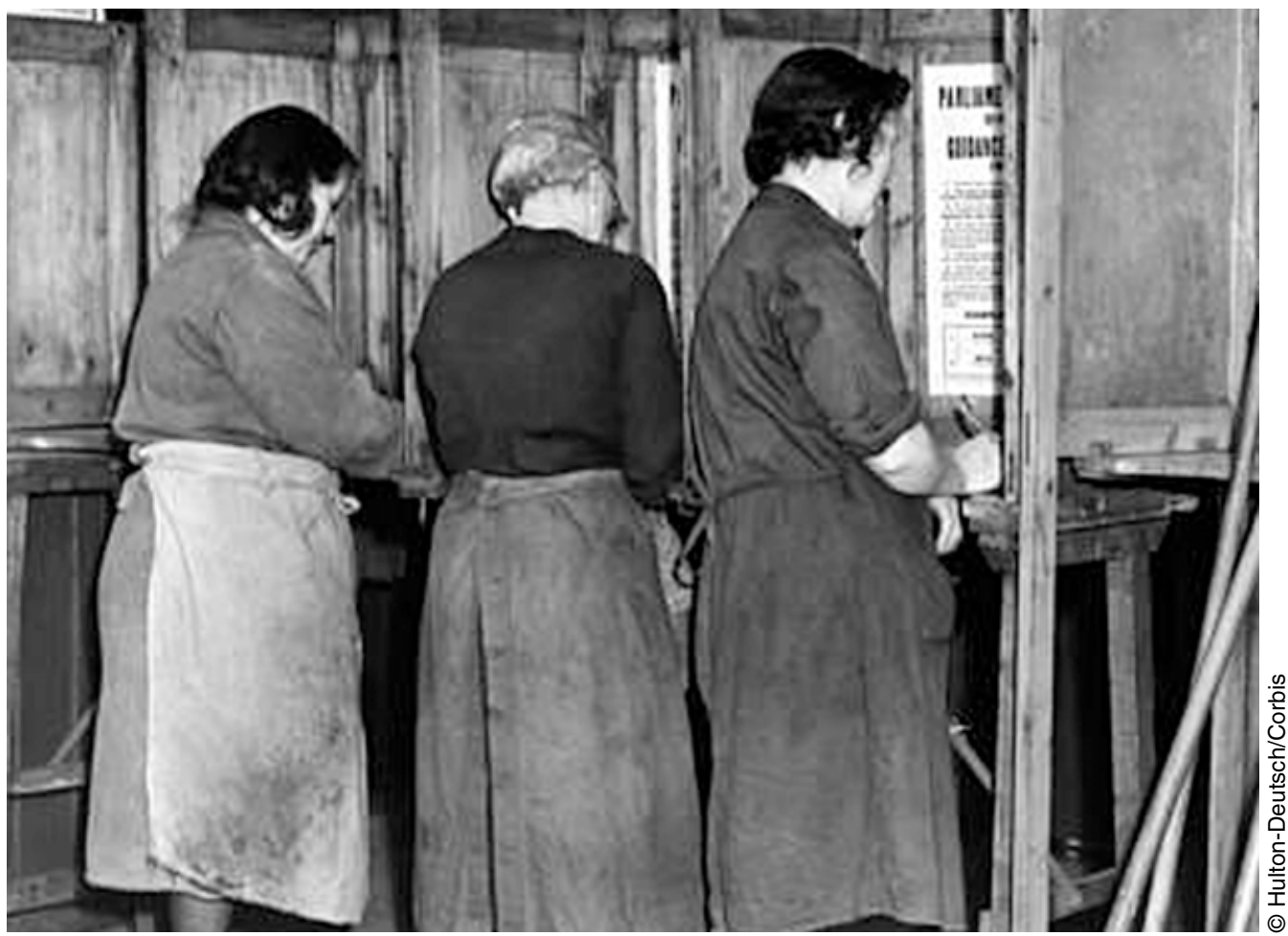
between empirical researchers and political philosophers. The former sometimes make easy assumptions about the desirability of equality of political voice; the latter often elaborate the optimal level of participation or participatory equality with only cursory consideration of the relevant empirical data. ${ }^{6}$ In most of our work, my collaborators and I have assumed the desirability of political equality-certainly the desirability of more political equality than we currently have in the United States. The purpose of this article is to question that preconception.

How important is it that political activity come equally from all citizens or - to make this point more precise and realisticthat it come with equal probability from each relevant type of citizen? Note that I am dealing with the equality and not the level of political activity. A few words on the distinction between the two may be useful. Participation fosters democracy in various ways. Some of its beneficial effects on democracy depend more heavily on the amount, or level, of political participation, while other beneficial effects depend on the equality of participation. Conveying a sense of membership or building community or creating legitimacy - all associated with citizen engagement-depends on the level of participation (that is, on how many participate). Declining political activity may signal a decline in citizen commitment and support for the polity; democracy seems weaker if few take part. Conversely, too high a participation rate may strain a democratic system, overloading it with demands that cannot be met. Political equality, however, is more closely related to another aspect of democratic functioning: equal protection of the interests of all citizens. This depends less on how many participate than on the representativeness of those who participate. ${ }^{7}$

\section{What Are We Equalizing?}

Before turning to the arguments in favor of and opposed to political equality, we need to take a closer look at what political equality means. What exactly would we equalize if we achieved political equality?

\section{What kind of activity?}

Much of the literature on political participation focuses on voting. There are several reasons for this: elections are the basic democratic institution, so voting is the basic citizen right; the aggregate of the vote determines who runs the government; voting is the most frequent political act; and, last, vast data resources—-both survey data and official election data—exist for the analysis of voting. But there are many other ways that citizens can take part in politics (direct contact, protest, and campaign activity or contributions, to name a few). These differ in significant ways, particularly in terms of the amount of information they convey about the needs and preferences of citizens and how much pressure they put on elites to respond. A full understanding of political inequality requires a consideration of these various means. I will not explore these differences here, since they are amply discussed elsewhere. ${ }^{8}$ Let me turn, rather, to some more general aspects of equality of political participation, each of which is relevant to a full understanding of what it would mean to make political voice equal. Equality of political voice may refer to the equal right to participate, the equal capacity and opportunity to participate, equality in the amount and nature of political activity coming from individuals or segments of society, equality in the reception of one's political voice (government officials hear what is said and give it equal 


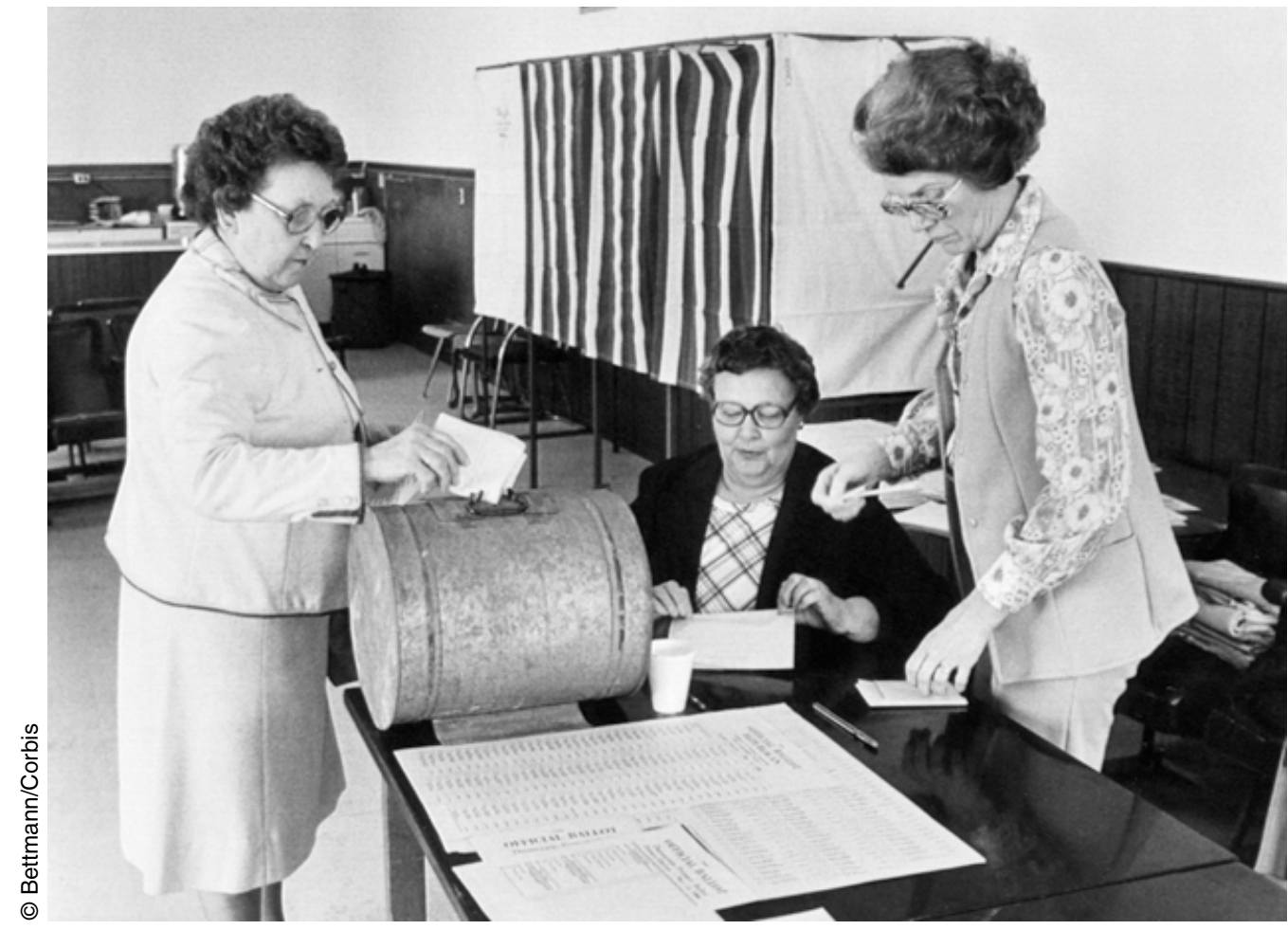

consequences of such rules. Restricting the voting rights of felons or former felons (under the explicit justification that felons have stepped outside the moral realm of citizenry) has the unintended consequence of restricting the voting rights of African American males. ${ }^{11}$ In former times, restrictions based on literacy (on the explicit justification that people need to be literate to be informed voters) had the effect of limiting the political activity of immigrants and blacks - a limitation that was surely intentional regarding African Americans in the South. Indeed, it is clear that "unintended" consequences are not always unintended. ${ }^{12}$

Another important factor is the locus of control over participatory rights. The fact that many aspects of voting rightsthe rights of felons, for

consideration), and equality in response (all citizens receive equal treatment in terms of policies and the implementation of policies).

\section{The equal right to participate}

This main democratic requirement includes, among other rights, universal adult suffrage; freedom of speech, the press, and other modes of political expression; and the right to organize political parties. These basic entitlements, held (more or less) universally, are considered necessary features of any democratic regime in almost all contemporary conceptions of democracy. As far as the United States is concerned, these are pretty much in place as a result of the 19th Amendment and the civil and voting rights acts of the 1960s. There are no legal barriers to citizen participation because of gender or race/ethnicity, and we have numerous legal protections against discrimination along those lines. ${ }^{9}$ A muted debate about age restrictions on participation was largely ended with the 26th Amendment.

There continue to be, however, disagreements over the universality of the right to participate. For instance, in many states, convicted felons do not have the right to vote; in some cases, that ban remains in effect for life. Relatively few, if any, restrictions apply to the speech rights of people in the United States, but there are restrictions on monetary contributions from noncitizens. ${ }^{10}$ And the issue of voting rights for long-term noncitizen residents is controversial.

Two aspects of these issues deserve special note. One is the distinction between the explicit, intended consequences of equality-limiting rules and the unintended equality-limiting instance-are under state control raises obvious issues of equality of rights.

So although most normative theories of participation are in agreement that equality of rights is a necessary condition for democracy, some controversies remain, both in fact and in terms of the ideal state. I will not focus on these controversies, but will turn to the next step in the path to effective citizen voice: the capacity to be politically active.

\section{Equal capacity and opportunity to participate}

As the old saying goes, freedom of the press is a wonderful right if you own a press. Rights require resources. One may need certain civic skills or competencies to participate effectively: information about elections so as to vote one's preferences, the capacity to speak publicly so as to communicate one's preferences, knowledge of political decision-making structures so as to intervene effectively in the decisional processes. One will need money to take part in politics as a financial contributor. And effective participation means equal opportunities to participate: equal access to information, to representatives, to government agencies, to organizations. Some activities are more dependent on resources than others. Activity in one's community or contacting an official requires more skill than does voting. Political contributions are the most resource dependent, requiring as they do the financial wherewithal. Voting is the political act least dependent on skills and for which the opportunity to act is most clearly presented to the citizen at election time. ${ }^{13}$

Resources and opportunity make political equality deeply dependent upon equality in other domains, such as education, income, connectedness, and health and well-being. In turn, 
political equality fosters equality in other domains by increasing the likelihood of policies that favor socioeconomic equality. This makes clear why some thinkers consider the capacity to exercise equal political voice to be of central concern in a democracy. Amartya Sen, in his discussion of what "goods" are important to equalize, refers to certain basic capabilities needed to achieve a full life. ${ }^{14}$ Political voice is one of these, since it allows the individual to acquire many other valued goods, such as income, education, health, and respect. But these, in turn, are general capabilities that enable the acquisition of political voice. In other words, political voice may be in the center of a virtuous circle of capabilities for those advantaged in a society, but a vicious circle of incapabilities for the disadvantaged.

\section{Equal voice}

If it is to entail equal consideration, however, equal participation may need to go beyond equal rights and equal capacity to include equal use of rights and capacity. One may have the right, the resources, and the opportunity to be active, but for various reasons-from ignorance to indifference-one may not choose to participate. Thus, equal rights and equal capacity do not necessarily mean equal voice.

Is anyone listening? The right to participate, the capacity to participate, and actual participation represent crucial steps toward equal consideration. But equal consideration may involve additional steps having to do with the response of governing officials to the expressed political voice. What if you send a message and no one pays attention? Two citizens may be equal in their voice (suppose that both vote, both write frequent and compelling letters to government officials, and both attend town meetings regularly), but one may for various reasons receive more attention than the other. Voting turnout may be equal across individuals or groups, but if some votes are not counted or if election districts are wildly different in size, electoral participation is not equal. If some letters are read and others left unopened, if some campaign workers or contributors have less of the ear of the candidate than do others, that is not equal voice.

Is anyone doing anything? The ultimate purpose-or, at least, one of the main purposes — of political activity is to get the government to do something in one's interest, whether that be a policy or a political favor. Political equality in its fullest sense would be equal policy output. Since policies do not always accomplish what they are intended to do, full equality of treatment would be a set of policies that treated all citizens equally. In some sense, these last two aspects of political equality-being heard and getting resultsrepresent its "true" instrumental meaning and are the ultimate payoff of equal participation and equal voice. They are difficult to observe and measure. The literature on the receipt of messages and the response to them is not as well developed as that on the messages sent. Making the connection is complicated since policies derive from many forces, not just citizen input. And sorting out why preferences and elite decisions overlap is not easy. ${ }^{15}$

In sum, political equality can mean many things, from the equal right to participate to equal treatment of all by the govern- ment. Equal political rights are fairly well established in the United States, though they are sometimes not enforced equally. But equal treatment for all is not possible, since individuals and groups have different needs and preferences, and policies favoring some are less favorable to others. Thus, this article concentrates on those aspects of political equality between the basic right to participate and the ultimate but unattainable result of equal treatment; that is, on equality across individuals and groups in the capacity to express political needs and preferences and in the actual use of that capacity. Democracies are sounder when the reason why some lose does not rest on the fact that they are invisible to those who make decisions. Equal treatment may be unattainable, but equal consideration is a goal worth striving for. And for the latter to exist, equal capacity to express political voice and equal expression of that voice are key.

\section{Participatory Equality: How Much Is There?}

Most of the empirical work on which I draw asserts that the ideal of political equality-in the sense of equal voice-is never achieved. The literature attempts to explain why that is the case. It may be useful to summarize some of the main conclusions of the empirical literature to set the stage for a debate on political equality as an ideal. ${ }^{16}$

(1) Though rights are equal, the actual use of such rights is stratified. Some people are more active than others. More important, there are persistent differences in the level of activity across politically relevant groups - that is, groups with distinctive needs and political preferences. Thus, if participation is a means by which citizen needs and preferences are communicated to governing elites - and if it is a significant means - the voices of individuals vary in their intensity and, more important in terms of policy outcomes, so do the voices of groups.

(2) In general, citizens who are advantaged when it comes to education, income, social standing, race/ethnicity, or gender are more politically active than those who are not.

(3) Unequal use of participatory rights rests on unequal capacity and opportunity. More active citizens are better endowed with participatory resources (such as time, money, and civic skills); they are more likely to be motivated (that is, to be interested in politics, to feel efficacious), to discern the connection between their own needs/preferences and public policy, and to be in social positions where they may be recruited to engage in politics. Resources, motivation, and recruitment opportunities often accompany positions of advantage in other spheres - a fact that accounts for the political advantage held by the socioeconomically advantaged.

(4) The relationship between motivation and resources is particularly relevant to the normative issues associated with political equality. In evaluating the extent to which there is inequality of voice, it is important to differentiate between those citizens who-to use a distinction that Kay Lehman Schlozman, Henry Brady, and I have used elsewhere-cannot participate because they lack the resources to do so and those who choose not to participate because they lack the interest or inclination. ${ }^{17}$ The former situation is a greater violation of democratic values than the latter. If an individual stays home 
from a town meeting because he or she lacks the funds to hire a baby-sitter or does not feel that he or she has the capacity to speak out effectively, we may consider this a violation of the norm of equal voice. If, however, an individual stays home to watch a favorite TV show or for lack of interest in local political issues, we do not feel that he or she has been deprived of a civic right or opportunity. ${ }^{18}$

(5) The relationship of political activity and the socioeconomic resources that foster it is a reciprocal one. If government policy and implementation of that policy are responsive to active citizens - and the evidence for this is convincing, though not as systematic and strong as that for individual citizen behavior-the result may be that less-advantaged citizens are less active because of the deficit of participation-enhancing factors among people in a low socioeconomic position. In turn, policy (say, in education or taxes or welfare programs) will be more responsive to the advantaged and active citizens, thereby increasing their advantage while providing relatively little for the disadvantaged. And so political inequality is reinforced.

(6) The reciprocal reinforcement of socioeconomic and political inequality depends heavily on the role of resources that foster participation and that derive from socioeconomic position. However, under certain circumstances, individuals and groups can become mobilized or otherwise motivated to political activity in connection with particular issues. When this phenomenon is accompanied by recruitment to activity of those who would otherwise be inactive because they lack the requisite resources, the socioeconomic/political circle can be broken. But recruitment to activity more often reinforces the socioeconomic stratification of political participation, as recruiters seek those who have the resource capacity to be effective activists. ${ }^{19}$

\section{Political Equality: Its Value and Its Dangers}

The above account simplifies a complex body of literature, but the general story is accurate. If equal consideration of the needs and preferences of all citizens is a central principle of democracy, then participatory inequality represents a violation of democratic principles. Is this, however, a serious challenge to the extent to which the United States may be said to function as an effective democracy? The participation literature usually deplores such inequality. Much of the empirical scholarship assumes that even if an ideal of fully equal participation is very likely unattainable, greater equality would be desirable. But would it be? Suppose that all citizens spoke with equal voice or that each politically relevant category of citizens (that is, all groupings of citizens that have different politically relevant needs or preferences) spoke with equal probability. What would democracy look like? Better in some ways, not so good in others.

\section{Why might we want political equality?}

The participation literature offers many reasons, including the following:

Political equality is intrinsically valued. Political equality is a valued good per se. The ability to express one's political views constitutes membership in the polity. It confers a sense of selfhood, of agency, of belonging. Put another way, there are some who denigrate the importance of voting, since voting rights and voting participation do not bring with them the solution to all or even most problems (consider the case of blacks in the American South, for example, or in South Africa). But those who denigrate the importance of the vote are almost always people who already have the right to vote. Democracy is valued not because democratic rule produces the most efficient or the most coherent policies (which it often does not do) or even the most just policies (which it may or may not do), but because it confers an important and valued status on its members: that of citizens who have the equal right and ability to control their own lives through influence over collective decisions. This status is not only a means to some other end; it is valuable in itself.

Political equality builds community. Societies are bound together by cooperative activity toward shared goals. This is how that precious commodity of social capital is formed. Since this involves horizontal connections, it implies the engagement of equals.

Political participation creates legitimacy. Democracy depends on citizens' voluntary acquiescence to the government (obedience to laws without constant police control, acceptance of election outcomes by the losing side, et cetera). The laws or electoral outcomes that one might not favor deserve respect because they were selected, through proper procedures, by the people (or at least the larger number of the people), with no individual or group given more voice in that decision than any other.

Political participation is educative. People learn about politics, democracy, and their own needs and preferences through participation for all. Equality is valuable in political activity just as it is in education.

Political equality enables equal protection of interests. Democracy implies equal consideration of the needs and preferences of all citizens. This instrumental aspect of political equality-the ability to inform the government of one's needs and preferences and to pressure the government to pay attention-is the key to that equal consideration. Those who express political voice, by voting or by speaking up or in other ways, are more likely to have government policies that pay attention to their needs and preferences. In this sense, political voice represents a general capacity to achieve many goals. Equality in political voice is, thus, a basic form of equality.

\section{Why might we not want political equality?}

In the empirical work on political participation, equal participation is assumed to be a good thing. But there is a dark side to equal participation. There can be too much of a good thing. Alongside the literature that implicitly or explicitly promotes political equality is an extensive literature warning of the dangers of too much and too equal political activity.

Democratic government is a term with internal tension. Democratic refers to rule by the people, with control flowing upward from citizens to decision makers. Government refers to authoritative decisions that control society and people's lives. The difficulty of putting the two terms together is that, on the democratic side, the people are many and varied, which makes 
the coordination of their needs and preferences difficult; and their attention to and knowledge of policy issues is limited, which ill equips them to judge among alternative policies. At the same time, government involves making complex policy decisions that balance the needs and preferences of many actors. The usual response to this tension is representative government, where the masses elect representatives who can-to use James Madison's language_- "refine and enlarge" the preferences of the public. Democratic government, it is generally accepted, is representative government. ${ }^{20}$ The political equality I am discussing does not question the fact that elected representatives inevitably have greater political voice than do ordinary citizens, or that the representatives are (or at least should be) better informed and more capable of governing. But what constitutes the optimum political voice for the ordinary citizen, and what are the costs and benefits of having that voice emanate equally from all citizens? Are citizens equally capable of responsible democratic participation-that is, participation that leads to effective democratic policy? Since education is the social characteristic that best predicts political activity and distinguishes "responsible democrats" from others, I will look at these questions from that perspective.

The foundation of political equality among citizens is the fundamental equality of human beings. For some earlier thinkers, this equality rests on the belief that all people are equal before God. A more secular pair of explanations, expressed by such democratic thinkers as Robert Dahl and John Rawls, ${ }^{21}$ is that people are reasoning beings capable of understanding the world and that they are moral beings capable of distinguishing good from bad. What does this mean for the ordinary citizen, and why is it the principle on which equal citizen voice is grounded? For one thing, it means that citizens should be good-or at least adequate-moral reasoners. Their preferences and values, whatever their substance, should have some coherence and be somewhat stable. It also may imply that their preferences should coincide with their interests. This point-whether individuals can judge their own best interests-is very complex, of course. Dahl essentially says that individuals may not know their best interests, but that it remains hard to find someone else who knows better. Furthermore, if preferences and values change from moment to moment or if they are incoherent and self-contradictory, it is hard to know how they can be given meaningful expression. ${ }^{22}$ Some would also argue that good citizens ought to be willing to transcend their own values and preferences. One component of this willingness is the ability to look beyond their own narrow selfinterest to consider the common good. Selfishness, according to this argument, is detrimental to democracy; citizens ought to be committed to some common good; and the process of taking part in politics should increase the likelihood that they will view politics from this broader perspective. Another component of the morally competent citizen is a willingness to accept principles of fair democratic procedure that allow for a multiplicity of viewpoints or doctrines to be expressed. Rawls refers to this as a free-standing overlapping consensus on a democratic process that involves tolerating alternative doctrines. ${ }^{23}$ This, as he notes and as many democratic theorists have noted before, is needed to main- tain a stable democracy given the inevitable plurality of competing doctrines subscribed to by citizens in a democracy.

In addition, citizens should be good (or at least adequate) social scientists. They should have enough information to know how to pursue their goals through politics. They should be capable of making causal inferences about how their activity might lead to desired outcomes (for instance, of figuring out whom to vote for or how one policy rather than another will affect their welfare). If they cannot reason about the political world, what do their expressed preferences mean? Thus, democratic voice would seem to rest on some capacity of citizens to be moral reasoners and social scientific reasoners. But what if citizens are not up to the task? What if they don't know what they want? What if they know what they want, but not how to get it? What if they care nothing for the common good? What if they can't be relied upon to go beyond their own preferred value system to tolerate others? Democratic voice becomes meaningless or undesirable. These considerations have led many philosophers of democratic government-from the founders of America to thinkers like Walter Lippmann or Joseph Schumpeter, ${ }^{24}$ to current observers of all political stripes who are leery of the public and its opinions-to express skepticism about the public, about too much democracy, about populist democracy.

The concern touches directly on political equality. What if citizens are unequally equipped for moral reasoning or social science analysis? Some are competent, others not. Consider this from the perspective of education. When there is unequal political activity, it is the better educated who tend to be more active. In our research on participation, my colleagues and I tried to discover why education is so potent a predictor of political activity. Is it because it makes people more informed? Makes them feel more efficacious? Makes it easier for them to see connections between their values/preferences and governmental action? Is it that it inculcates the norm that one ought to be a participant? Does it increase the store of resources that people have-skills that make one an effective participant, or income that is useful for contributing to political campaigns or causes? Does it put individuals into networks, so that they are surrounded by others who are active and who can help them act effectively? The answer is "all of the above." Education fosters activity through its effect on information, skills, values, resources, networks, and more. No wonder it is so potent.

Some simple data make this point clear. Compare individuals who have no college education with college graduates. The latter are more active in any of the activities we measure, and by a long shot. They are, for instance, twice as likely to have contacted a government official (a good way to express political voice) than are people with only a high school education. They are one-third more likely to vote, three times as likely to work in a campaign, and twice as likely to be community activists; they give about 12 times as much money to political campaigns and causes. (See Figure 1.) High school graduates contribute on average $\$ 15$; those with some college contribute $\$ 53$; and college graduates rise to $\$ 186$ worth of campaign contributions. ${ }^{25}$

Furthermore, numerous social science analyses show that education is the best predictor of the quality of citizen engagement. 
Figure 1

Political Activity by Education

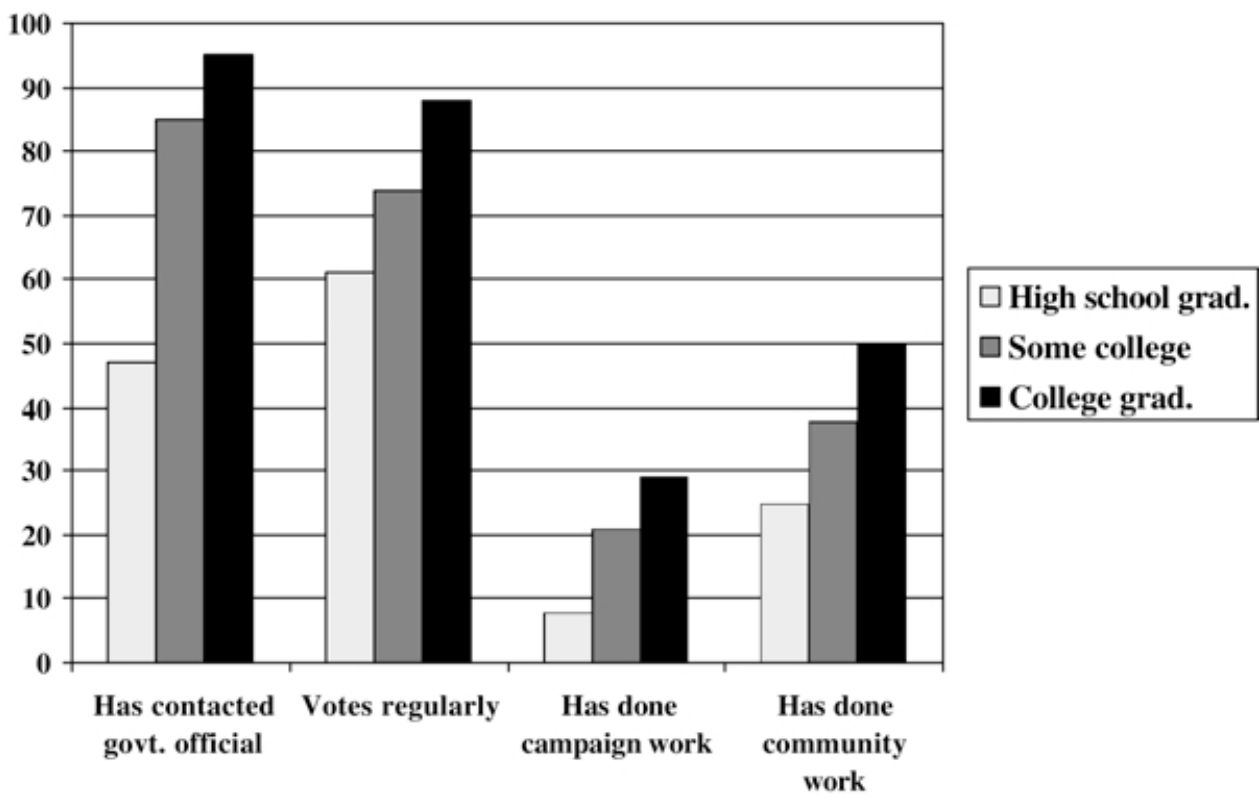

Source: Citizen Participation Study. For further information on the study, see Verba et al. 1995. get twice as many information items right as uneducated citizens: the mean information score for those with no college is 3.7 , compared with 4.8 among those with some college and 5.7 among college graduates. When the educated contact government officials, they are four times as likely to raise an issue that has broad relevance, rather than some issue limited to themselves and their family; they have, thus, more civic concern. They are substantially likely to support the right of someone who opposes religion to speak in the community. And on and on. ${ }^{26}$ The conclusion is clear. It is good for democracy that the educated are more active: they are higher quality citizens.

The distinction between moreeducated and less-educated citizens holds-though not as strongly-for other distinctions that divide the more advantaged from the less advantaged, whether based on income or kind of job or race/ethnicity or gender. The cause of all these differences may rest in educational disparity; nevertheless, however one defines disadvantaged, if one equalizes participation between the advantaged and the disadvantaged, the quality of that participation will go down.

The limitations of citizens as moral reasoners (unsure of what they want and/or perhaps wanting things antithetical to democracy), coupled with their weaknesses as social analysts (ill-informed and unable to see the causal connections that would allow them to act in ways that would get them what they want), call into question the role of citizen participation in a democracy. Schumpeter provides the classic case for limited participation. ${ }^{27}$ In the Schumpeterian analysis, electoral participation is the key role for citizens, who vote on leaders and then are finished. Elites are supposed to be left to rule. That does not end citizen control, because leaders must worry about the next election. The essential participatory role is the citizen as retrospective voter. For Schumpeter, the right to vote is crucial, but that's it.

This position is attractive. Elections are the democratic institution on which everything else rests. Election results are, with rare exceptions, dispositive when it comes to who is in charge. And elections are the most 
egalitarian of activities. More citizens vote than take part in any other way, and voting is more equally distributed across the citizenry than is any other act. Citizen control via retrospective voting does not strain citizen competence and gives ruling elites the space to make the carefully considered expert decisions needed to run a complex society.

This restrictive notion of democracy — with little room or need for citizen activity — would be an adequate approach to a government that gave equal consideration to all citizens if (1) activists did not differ in their preferences from inactive citizens and (2) voting in elections was the dominant, perhaps sole, means of citizen activity. Let us consider both of these conditions.

If activists do not differ from inactive citizens, it matters little that some citizens are active and some inactive. The former can speak for the latter. But if they do differ, is it in politically relevant ways? How do their preferences compare in regard to pending political issues? Aside from views on pending issues, do the inactives differ from the actives on the issues they would bring forward if they were more active? Are there- to resurrect a word from earlier political science- "nonissues" hidden in inactive populations? And even if the inactives differ neither in preferences nor in agendas, are their politically relevant needs different from those of the actives? Policy makers do not merely listen to who speaks; they observe what citizens are active and see what they need. Visibility applies to activity both in terms of preferences that people have and needs that they may have but do not express.

In their study of voting turnout, Raymond Wolfinger and Steven Rosenstone make an important point that has become part of political science common wisdom: although voters differ from nonvoters in their demographic composition (their level of education, their income, et cetera), they differ little in their policy preferences as measured by their responses to a series of survey questions about attitudes on government welfare and other policies. ${ }^{28}$ Schlozman, Brady, and I replicated the Wolfinger and Rosenstone analysis and confirmed that there was little attitudinal difference between voters and nonvoters. ${ }^{29}$ Others have found differences, but usually not large ones. ${ }^{30}$ In addition, various analysts have shown that the outcome of an election would rarely be changed if one eliminated turnout differentials among groups-if, for instance, everyone voted. ${ }^{31}$ This is a corrective to a common view that an increase in voting turnout is coterminous with an increase among the voting population in the proportion of those who are less well off. Those who believe that equalizing turnout among those who currently are less likely to vote would produce a major change in the electoral mandate ${ }^{32}$ might well be disappointed by the results of massive vote mobilization.

However, since the existence of politically relevant differences between the active and inactive citizens is at the heart of the significance of participatory inequality, it is useful to look at this more closely using the range of information available in the American Citizen Participation Study. ${ }^{33}$ The similarity in many policy positions of voters and nonvoters is an important point, but its magnitude can be overstated. Difference is measured in a comparison of responses by voters and nonvoters to standard
National Election Studies questions on a set of political issues. If one expands the scope of inquiry, one gets different results. First, we must take a broader view of politically relevant attributes, encompassing not only demographics and policy positions as expressed in response to survey questions but also policy-relevant circumstances and the actual content of participation. We must also take a broader view of political activity, moving beyond electoral turnout to include various kinds of activity that can convey more precise messages to policy makers as well as activities such as campaign contributions or campaign work, where activists are not limited in the amount of their activity by the enforced equality of the single vote.

When we do this, we find that active and inactive citizens are not the same. Differential voice means that different things are being said—especially by activities that can easily carry a message. In our participation study, we consider not only active and inactive citizens' preferences for social policy, but also their needs and life circumstances. When we move to the level of needs and ask whether respondents have faced serious economic deprivation, we find much wider disparity across activity groups. Further, when we look at those citizens perhaps most dependent on government programs - citizens receiving means-tested benefits—-we find even wider variance. And if we expand our scope to consider different political acts, we find that the divide between the active and inactive citizens increases with the difficulty of the act; more relevant to our current concern, the disparity grows with the extent to which the act accurately communicates the needs and preferences of the actor and the extent to which the act has clout-i.e., is likely to make the target of the act sit up and take notice.

Figure 3 presents data on several characteristics of the population as a whole and of various activist groups: regular voters, people who report contacting officials, community activists, protesters, and contributors to political campaigns and causes. Thus, we get a wide range of activity types. And for each of the groups of activists, Figure 3 presents data on their political attitudes (the percent liberal in relation to some standard measures of economic liberalism) ${ }^{34}$ and their needs (the percent who have faced financial strain in the past year ${ }^{35}$ and the percent who received means-tested benefits). ${ }^{36}$ We can therefore compare various activities in terms of how they represent the preferences and the needs of citizens.

In general, the data show that activists are most similar to the population as a whole in terms of their answers to the questions about economic policy. They differ somewhat more on measures of need; in particular, contributors are substantially more likely than the public in general to report that they faced no financial strain in the previous year. And when one considers the receipt of meanstested benefits, it becomes clear that activists, including voters, are much less likely to come from the ranks of those who may be most dependent on government policies. The contributors contain almost no one who has been dependent on governmental welfare.

Consider those with clear need for government support: those already receiving welfare benefits. In the three modes of activity that might be particularly relevant for them-getting in touch with public officials, attending protests and demonstrations, and being active in the community-there is severe underrepresentation. Contacting is, presumably, especially important for citizens 
Figure 3

Activity Rates for Various Groups

3.a. Percentage of citizens who are liberal on economic policy

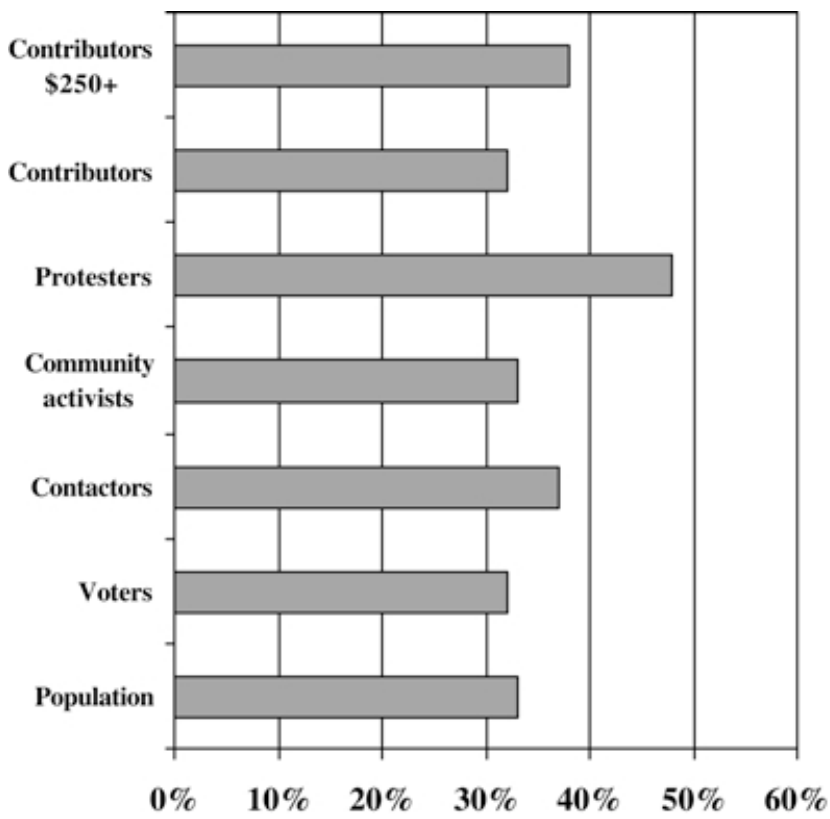

weapon of the weak for those who do not have the resources to be otherwise active, but it is more frequently used by those not in the most need. Protesters are, however, significantly more likely to be liberal than the population as a whole. This suggests that protesters may support the needs of those on welfare, but not based on their own experience.

We can take the analysis a step further and look at the political agenda. Suppose the disadvantaged were more active; would they put different issues on the agenda than the advantaged do? Are there needs and preferences that would be more prominently placed before governmental officials if the silent were less silent? It is, of course, difficult to know what the quiescent would say if they spoke up; but we can look at those disadvantaged citizens who do convey specific messages, and at officials, to obtain some estimate of who receive government benefits, since ensuring the flow of benefits may entail dealing with officials. Recipients of meanstested benefits, however, are substantially underrepresented among the contactors; and they are about half as likely as other citizens to be community activists as their proportion in the population would warrant. Interestingly, even protesters are less likely to have received means-tested benefits. Protest may be the

\section{3.b. Percentage of citizens who received means-tested benefits}

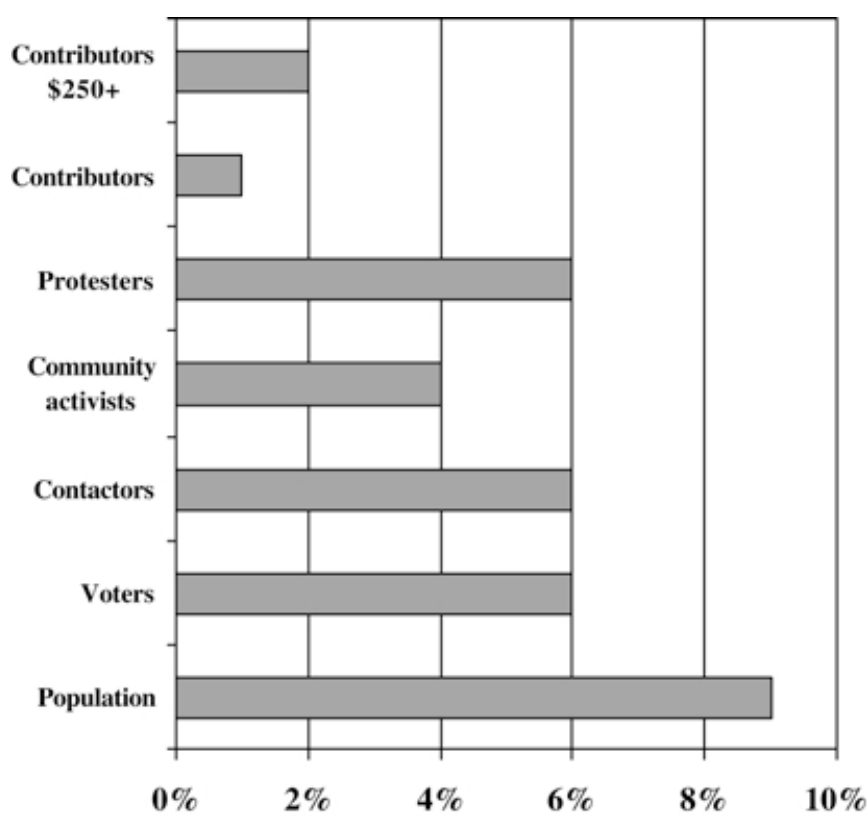

Received means-tested

Source: Citizen Participation Study. For further information on the study, see Verba et al. 1995. benefits

what the latter would hear if more of the disadvantaged sent such explicit communications. In the Citizen Participation Study, we asked active respondents to tell us if there was some issue or subject matter that animated their activity. If we look at the information-rich acts - those that actually convey a message, such as a letter to an official, participation in a protest, or a campaign contribution accompanied by a communication as to why the individual is making the contributionwe find, as we would expect, that the disadvantaged are about a third as likely as the advantaged to send informative messages to officials. (See Table 1.) What is interesting, however, is how different such messages are when we compare the advantaged and the disadvantaged. The disadvantaged are more than twice as likely as the advantaged to refer to basic needs_food, housing, health care, and the like. Advantaged citizens, in contrast, are three times as likely as the disadvantaged to discuss taxes, government spending, and the budget. They are more likely to put education, the environment, social issues, and international issues on the agen$\mathrm{da}$; the disadvantaged are more likely to refer to issues of drugs and violence. The data suggest that the relative quiescence of the disadvantaged affects the shape of the issues put 
3.c. Percentage of citizens who had no financial problems

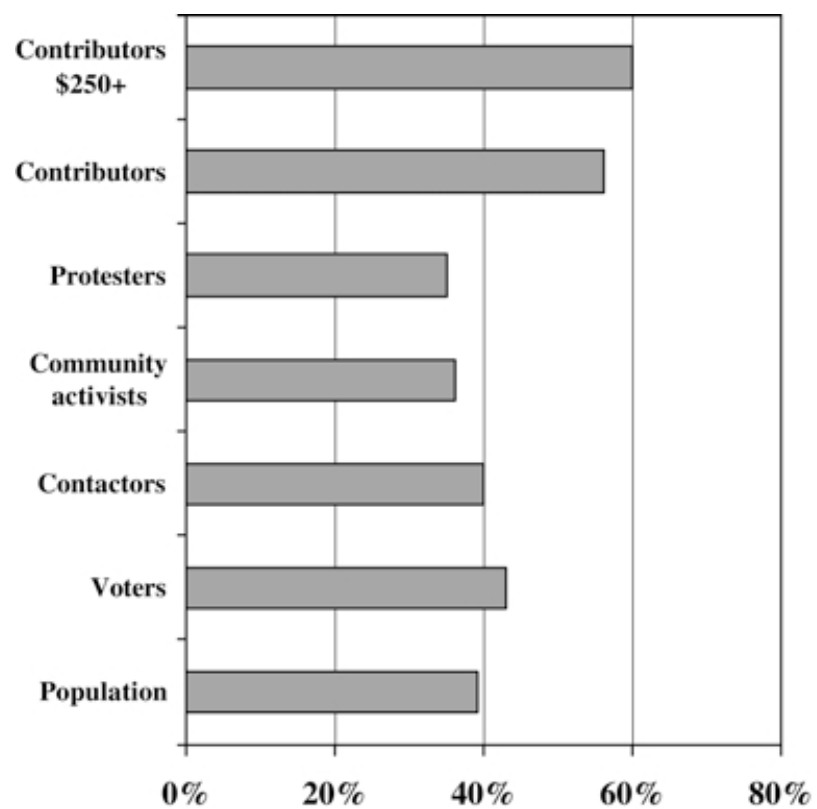

quate representation for the citizenry? A democratic system rooted in citizen voting could provide all citizens with equal voice if all citizens voted (or a representative set of citizens voted), if citizens limited themselves to the vote, and if they voted based on retrospective performance evaluations of the elected officials. Then, that most powerful democratic citizen-the median voterwould rule, and the system might not tilt in the direction of the already advantaged citizens, whose voice is louder. But not all citizens vote; thus, the median voter is not the median citizen. The differences are not vast, but even our most egalitarian mode of activity, voting, tilts upward. The median voter is more educated, somewhat better off financially, and less likely to be needy than the median citizen. (See Table 2.) And citizens do not all have equal before the government by the citizenry. If less-advantaged citizens were more visible, government programs involving the basic needs of the disadvantaged would be more likely to appear on the political agenda.

Participation tilted toward the advantaged, then, might yield a higher quality of citizenry, but it also means less equal voice. This brings us back to the Schumpeterian limited notion of election-based democracy. Would such a system provide ade- clout as voters. Some gain electoral power by giving moneyand some gain even more by giving a lot of money. In this way, they buy votes - if not the votes of legislators directly, then the votes of those induced by campaign spending to select the contributor's candidate.

As Table 2 shows, the median contributor-especially the median big contributor - is very different from the median citizen or the median voter. Insofar as contributions move the electorate and

\section{Table 1}

\section{What Respondents Say: The Subject Matter of Information-Rich* Activities}

\begin{tabular}{|c|c|c|c|}
\hline & All respondents & $\begin{array}{l}\text { Advantaged } \\
\text { respondents }^{\star *}\end{array}$ & $\begin{array}{l}\text { Disadvantaged } \\
\text { respondents }^{\star \star *}\end{array}$ \\
\hline $\begin{array}{l}\text { Send at least one information-rich message } \\
\text { Among those who do: }\end{array}$ & $42 \%$ & $64 \%$ & $23 \%$ \\
\hline$\%$ who send at least one such message on basic needs & $15 \%$ & $11 \%$ & $24 \%$ \\
\hline$\%$ who send at least one such message on govt. spending/taxes & $15 \%$ & $18 \%$ & $6 \%$ \\
\hline$\%$ who send at least one such message on education & $18 \%$ & $21 \%$ & $11 \%$ \\
\hline$\%$ who send at least one such message on social issues & $12 \%$ & $14 \%$ & $6 \%$ \\
\hline$\%$ who send at least one such message on violence/drugs & $9 \%$ & $8 \%$ & $12 \%$ \\
\hline$\%$ who send at least one such message on environment & $8 \%$ & $10 \%$ & $3 \%$ \\
\hline$\%$ who send at least one such message on international issues & $3 \%$ & $5 \%$ & $0 \%$ \\
\hline
\end{tabular}

*Information-rich activities are those through which explicit messages are sent to government officials. Some examples are letters, protests, campaign contributions accompanied by an explicit message, community activity, or activity on local boards. Specific issue responses are for those who engaged in an information-rich activity and reported a "codable" (interpretable) subject matter associated with the act.

${ }^{* *}$ Advantaged: had at least some college, and family income is $\$ 50,000$ or more.

${ }^{* \star *}$ Disadvantaged: had no education beyond high school, and family income is $\$ 20,000$ or less.

Note: The time frame for these results is one year. Individuals who fall between the categories "advantaged" and "disadvantaged" are not tracked in this table.

Source: Citizen Participation Study. For further information on the study, see Verba et al. 1995. 
the election closer to the concerns and policy preferences commensurate with the contributors' positions - which is, one would assume, what they want their contributions to do-a system of democratic control limited to the vote would not entail the equality of voice that the "one vote per person" ideal would require.

Of course, the model of electoral control by voters who cast their ballots and then retire to private concerns until the next election is not an accurate description of what happens. Between elections, all the other modes of activity continue-including those that influence elections, like campaign contributions. And those activities are even more stratified than the vote.

In sum, inequality in political voice exists and is consequential. Some speak louder than others and speak in a different voice. And - to push the figure of speech a bit too far, perhaps-the more the mode of speaking is amplified (by a large contribution or an eloquent letter), the more the voice is different. This does not obviate the reservations that have been expressed about fully equal activity. It may be that the quality of participation would go down if equality increased. Perhaps the government would be faced with demands for an inefficient or short-sighted economic policy whose long-term impact would be negative even for those who wanted the policy. Educated and affluent citizens might prefer policies that were better and more clearly reasoned. However, the goals that they pursued might be ones that benefited them to the detriment of the economy as a whole or to the less well-off members (consider the Savings and Loan industry in the 1970s or the Enrons of the 2000s). Equal participation might also lower the quality of participation if it meant rule by citizens less committed to such democratic values as free speech or minority rights. There is a tension between freedom and equality. However, such worries may be exaggerated. Civil libertarians raised concerns after September 11, 2001, about limitations on free speech or unfair treatment of Muslims; but if there were dangers to freedom in the post- $9 / 11$ reactions, they came from security concerns among governing elites, not from popular demand. Furthermore, as Sen has stressed, liberty and equality are closely and positively related. Exercise of the former often requires a substantial amount of the latter. ${ }^{37}$

\section{What Can Be Done?}

Is it possible to change the participatory process so that the playing field is more level and the players are more equally trained and equipped to compete? The Civic Voluntarism Model (CVM) with its stress on resources, motivation, and recruitment-suggests three routes. One would be a change in the underlying social and economic conditions that create differences among individuals and groups in their capacity to be active; a second would be an increase in the political motivation of less-advantaged citizens; and a third might involve the recruitment of people whose socioeconomic characteristics would otherwise lead them to be inactive. Direct governmental intervention to level the playing field would bypass the unequal consequences of the CVM.

\section{Resource disparity}

Political inequality in the United States is embedded in the basic nonpolitical institutions of society. In a variety of works, my colleagues and I have shown that differences in political activity across individuals derive from their positions and experiences in the family of origin, in schools, in the family as an adult, in the work force, in religious institutions, and in nonpolitical associations. ${ }^{38}$ It is important to understand how this process, expressed in our CVM, results in the tilting of the participant population in favor of some preferences or agendas or needs over others. It is not so much that particular preferences are held more strongly, or some agenda items are more compelling, or some needs more pressing, and that these preferences or agendas or needs drive participation. Rather, it is that people with certain social characteristics, such as more education, have more capacity-they have the relevant resources - to be active. That capacity is issue-neutral. People with greater resource capacity, whether from the right or the left, are more active. The tilt in the messages conveyed via activity comes from the fact that those with more capacity do not come in equal proportions from the right and the left. This fact can be seen most simply if we apply the CVM to predict activity for people with different policy preferences or needs.

Table 3 reports a simple regression analysis predicting political activity for several kinds of citizens: those who favor more government intervention to help needy people and those who oppose such government activity, as well as those who report real economic need in the past year and those who report no such need. ${ }^{39}$ As Table 3 shows, the same process by which resources accumulated in nonpolitical institutions bring people into political life works for liberals and conservatives. Similar results are found if we divide the population along lines of need. Among both the needy and the not-needy, the CVM works to generate political activity.

The data in Table 3 tell us

\section{Table 2}

The Median Citizen, Voter, and Contributor in the 1988 Election Year

\begin{tabular}{lccc}
\hline & $\begin{array}{c}\text { Median grades of } \\
\text { schooling completed }\end{array}$ & $\begin{array}{c}\text { Median family } \\
\text { income }\end{array}$ & $\begin{array}{c}\text { Percent with little } \\
\text { need* }^{*}\end{array}$ \\
\hline Citizens & 12.5 & $\$ 31,600$ & $62 \%$ \\
Voters & 13.5 & $\$ 37,500$ & $69 \%$ \\
Campaign contributors & 15.5 & $\$ 42,300$ & $75 \%$ \\
Contributors \$250+ & 16.0 & $\$ 59,500$ & $83 \%$ \\
\hline
\end{tabular}

${ }^{*}$ Report no financial strain in previous year.

Source: Citizen Participation Study. For further information on the study, see Verba et al. 1995. a good deal about the dynamics by which some preferences and needs are given voice while others are not. Citizens participate for many reasons: because they are asked, because it is a habit, because they believe a good citizen ought to participate. They also participate for more purposive reasons: for instance, to influence public officials 
Table 3

Predicting Political Activity Using the Civic Voluntarism Model

3.a. Among conservatives and liberals on government economic policies*

\begin{tabular}{|c|c|c|c|c|c|c|c|c|}
\hline \multirow[b]{2}{*}{ Variable } & \multicolumn{4}{|c|}{ Conservatives } & \multicolumn{4}{|c|}{ Liberals } \\
\hline & B & SE B & $\mathrm{T}$ & Sig $T$ & B & SE B & $\mathrm{T}$ & $\operatorname{Sig} \mathrm{T}$ \\
\hline Education & 0.13 & 0.03 & 3.96 & 0.00 & 0.20 & 0.04 & 4.72 & 0.00 \\
\hline Family income & 0.19 & 0.06 & 3.38 & 0.00 & 0.25 & 0.08 & 3.27 & 0.00 \\
\hline Civic skills & 0.15 & 0.03 & 5.11 & 0.00 & 0.16 & 0.05 & 3.39 & 0.00 \\
\hline Recruitment & 0.18 & 0.04 & 4.80 & 0.00 & 0.21 & 0.05 & 3.98 & 0.00 \\
\hline Political engagement & 0.58 & 0.04 & 14.79 & 0.00 & 0.52 & 0.05 & 11.01 & 0.00 \\
\hline \multicolumn{9}{|l|}{ Controlling for: } \\
\hline Race (black) & 0.03 & 0.03 & 1.01 & 0.31 & 0.02 & 0.02 & 0.93 & 0.35 \\
\hline Ethnicity (Latino) & 0.03 & 0.03 & 0.89 & 0.37 & -0.04 & 0.03 & -1.27 & 0.20 \\
\hline Gender (female) & -0.02 & 0.01 & -1.36 & 0.17 & 0.01 & 0.01 & 0.73 & 0.47 \\
\hline Age & 0.00 & 0.00 & 4.73 & 0.00 & 0.00 & 0.00 & 5.34 & 0.00 \\
\hline Age (over 65) & -0.02 & 0.02 & -0.66 & 0.51 & -0.07 & 0.03 & -1.99 & 0.05 \\
\hline (Constant) & -0.20 & 0.03 & -6.35 & 0.00 & -0.27 & 0.04 & -6.46 & 0.00 \\
\hline
\end{tabular}

Activity score for conservatives: 2.30

Activity score for liberals: 2.10

${ }^{*}$ Respondents are ranked as liberal or conservative on an opinion scale about government provision of jobs and government spending on welfare programs.

Source: Citizen Participation Study. For further information on the study, see Verba et al. 1995.

to act in some way that serves their needs or preferences. ${ }^{40}$ These needs and preferences, as I have shown, receive differential voice, which derives less from the nature of the needs and preferences than from the resource endowments of those who hold them. The process by which individuals acquire resources is issue-neutral, as is the role of those resources in fostering participation. In sum, the CVM works the same for liberals and conservatives, for the more needy and the less needy. But the institutional positions of individuals with dissimilar needs or preferences are different —in the amount of education people have, the kinds of jobs they have, and the resources that they pick up from such positions. Thus, differential resource endowments lead to differential voice, and unequal nonpolitical social processes lead to unequal political outcomes.

To reduce inequalities in political activity that are fostered by these socioeconomic processes would, therefore, take nothing less than reducing socioeconomic inequalities in income, education, and access to better jobs. It is not in my competence to analyze whether or how this might happen, but this is likely not a shortrun fix. Indeed, the socioeconomic tilt of activity toward the participation of the better-off is self-reinforcing, with political activity increasing or at least supporting the current socioeconomic

\section{3.b. Among not-needy citizens* and needy citizens}

\begin{tabular}{|c|c|c|c|c|c|c|c|c|}
\hline \multirow[b]{2}{*}{ Variable } & \multicolumn{4}{|c|}{ Not Needy } & \multicolumn{4}{|c|}{ Needy } \\
\hline & B & SE B & $\mathrm{T}$ & Sig T & B & SE B & $\mathrm{T}$ & $\operatorname{Sig} T$ \\
\hline Education & 0.16 & 0.02 & 6.61 & 0.00 & 0.20 & 0.04 & 5.05 & 0.00 \\
\hline Family income & 0.22 & 0.04 & 5.17 & 0.00 & 0.30 & 0.09 & 3.27 & 0.00 \\
\hline Civic skills & 0.15 & 0.03 & 5.95 & 0.00 & 0.13 & 0.04 & 3.27 & 0.00 \\
\hline Recruitment & 0.23 & 0.03 & 7.08 & 0.00 & 0.22 & 0.04 & 5.21 & 0.00 \\
\hline Political engagement & 0.52 & 0.03 & 16.98 & 0.00 & 0.49 & 0.04 & 12.33 & 0.00 \\
\hline \multicolumn{9}{|l|}{ Controlling for: } \\
\hline Race (black) & 0.01 & 0.02 & 0.61 & 0.54 & 0.03 & 0.02 & 1.67 & 0.10 \\
\hline Ethnicity (Latino) & -0.02 & 0.02 & -1.02 & 0.31 & 0.01 & 0.03 & 0.43 & 0.67 \\
\hline Gender (female) & -0.00 & 0.01 & -0.04 & 0.97 & -0.02 & 0.01 & -1.59 & 0.11 \\
\hline Age & 0.00 & 0.00 & 5.94 & 0.00 & 0.00 & 0.00 & 4.04 & 0.00 \\
\hline Age (over 65) & -0.01 & 0.02 & -0.68 & 0.49 & -0.05 & 0.03 & -1.66 & 0.10 \\
\hline (Constant) & -0.20 & 0.03 & -7.83 & 0.00 & -0.17 & 0.04 & -4.77 & 0.00 \\
\hline
\end{tabular}

Activity score for the not needy: 2.30

Activity score for the needy: 1.80

*Did not have trouble paying for basics (food, rent, or medical care) in previous year.

Source: Citizen Participation Study. For further information on the study, see Verba et al. 1995. 
inequalities. The CVM process leading to political activity is politically neutral in that it favors people with resources, not people with particular views. However, though the process is neutral, the outcome tilts the participant population in certain directions because of resource differences.

The socioeconomic basis of political inequality makes clear that this is a form of "durable inequality." ${ }^{41}$ In recent work, my colleagues and I have shown how political inequality is transmitted from generation to generation, in large part through the inheritance of socioeconomic position. ${ }^{42}$ In addition, political and socioeconomic inequality form a mutually reinforcing circle. Socioeconomic inequality produces inequality in political voice; this in turn fosters policies that favor the already advantaged; and these policies reinforce socioeconomic inequality.

\section{Political motivation}

Disadvantaged citizens are less likely than the advantaged to be politically motivated. They have less interest in politics and are less likely to believe that they could be efficacious if they were politically active. This may be part of a vicious cycle of political disengagement. Those with fewer resources are less likely to be interested in what they cannot influence. They may have learned that politics is of little use to them from observing the role of resources they do not possessmoney in particular.

Can their motivation be increased? The source of much political motivation appears to be schooling; equalizing schooling would thus be one way of equalizing political participation. It would also increase the quality of participation. This, of course, is a long-sought and elusive goal. People can also become active for specific political reasons: that is, they can be motivated by a particular preference for a cause or policy or candidate. Individuals can become engaged in an issue that-for whatever self-interested or social or religious or other reason-leads them to activity. In such a case, socioeconomic resources do not necessarily dominate the path to politics.

My colleagues and I have focused on the abortion issue as an example of political activity motivated by a particular cause. Lessadvantaged individuals-mostly religious pro-life citizensbecame more active than one might otherwise have predicted. Such issue-based mobilization of people who are not particularly well endowed with resources and who might, therefore, otherwise be inactive illustrates a way in which the socioeconomic tilt of participation might be diminished. It also demonstrates that such mobilization may not exist around issues that would result in greater socioeconomic equality. Furthermore, of course, issue mobilization may also be directed at the advantaged, thereby increasing the socioeconomic tilt of political activity.

\section{Political recruitment}

Many times in American history, disadvantaged people have been mobilized around group membership on a particular issue. However, the United States is not laden with those institutionspolitical parties or trade unions - that mobilize the disadvantaged. ${ }^{43}$ In many countries, the parties of the left mobilize ordinary citizens, particularly disadvantaged citizens who might otherwise be inactive. The Democratic Party in the United States may have done this more effectively in the past, but the mobilization capacity of political parties in general has diminished in recent decades ${ }^{44}$-and the mobilization of the disadvantaged does not seem to be high on the Democratic Party's agenda. Figure 4 contains some quite relevant data on recruitment by both major political parties. As one can see, the two parties do differ in terms of their supporters. Republican identifiers are more affluent than the average citizen, and Democratic identifiers are less affluent; and the difference is fairly substantial. Republican and Democratic voters differ in a similar way, though in each party-as the data in Table 2 lead us to expect-voters are somewhat more affluent than the average citizen. However, when we look at the family income of those recruited to political activity through a party contact, two things become 
apparent. Both parties recruit campaign workers and campaign contributors from the more affluent of their supporters; in particular, those recruited to contribute money are substantially more affluent than the average citizen. And despite the income difference between Republican and Democratic supporters, or between Republican and Democratic voters, the difference between the two parties in whom they recruit for contributions is quite small. Both parties go where the money is. ${ }^{45}$ In general, as my collaborators and I have recently shown, mobilization to politics is more likely to bring in people who would otherwise be active, not those who would be otherwise inactive. Recruitment, then, may lead to some participation from disadvantaged citizens who would not otherwise be active, but overall it increases the stratification of activity. ${ }^{46}$

\section{Direct government intervention}

Whatever the underlying causes of political inequality, direct government intervention mandating participatory equality would be the most direct route to a level playing field. However, a full-scale program to give everyone an actual equal voice would be very difficult to implement, would involve severe governmental intervention, and would require limitations on freedom. It could be achieved by putting a floor and a ceiling on activity. A floor would require all to be active at some defined level—making citizens vote, attend political meetings, or contribute financially to causes or campaigns. Voting is compulsory in some countries, usually with minor penalties for failure to vote. It is an innocuous requirement, perhaps, but it would go against the grain in America and not add much to political equality. ${ }^{47}$ Compulsory attendance and contributions smack much more of authoritarian techniques than of democratic ones. A ceiling on political activity exists in relation to the vote (one person/one vote). But ceilings on money have run up against court interpretations of the First Amendment, as would any limitation on writing letters, protesting, or attending meetings.

This does not mean that there is little room for direct governmental action. Campaign finance reform remains an elusive goal, but it may be possible to reduce the unequal effects of the dominance of money in electoral politics without butting up against constitutional objections. The increased role of money has been a major cause of growing political inequality. In addition, careful scrutiny of the voting and registration processes may decrease some inequalities in access to the polls revealed in the 2000 presidential election. And reconsideration of the laws governing the voting rights of ex-felons might reduce some-possibly unintended-racial biases in the election process.

\section{Conclusion}

This paper has focused on the equality of citizen participation and the reasons that we do and do not want it. On balance, although the reasons to fear political equality are not to be ignored, they are more than counterbalanced by the problems associated with inequality among citizens in their political voice. Political equality is an important ideal. While it is true that we will not achieve it soon, this is no reason not to continue trying.

\section{References}

Almond, Gabriel A., and Sidney Verba. 1963. The Civic Culture: Political Attitudes and Democracy in Five Nations. Princeton: Princeton University Press.

Bartels, Larry M. 2002. Economic inequality and political representation. Paper presented at the annual meeting of the American Political Science Association, 29 August, Boston.

Bennett, Stephen Earl, and David Resnick. 1990. The implications of nonvoting for democracy in the United States. American Journal of Political Science 34:3, 771-802.

Brady, Henry E., Sidney Verba, and Kay Lehman Schlozman. 1999. Prospecting for participants: Rational expectations and the recruitment of political activists. American Political Science Review 93:1, 153-68.

Brehm, John. 1993. The Phantom Respondents: Opinion Surveys and Political Representation. Ann Arbor: University of Michigan Press.

Burns, Nancy, Kay Lehman Schlozman, and Sidney Verba. 2001. The Private Roots of Public Action: Gender, Equality, and Political Participation. Cambridge: Harvard University Press.

Dahl, Robert A. 1989. Democracy and Its Critics. New Haven: Yale University Press.

DeNardo, James. 1980. Turnout and the vote: The joke's on the Democrats. American Political Science Review 74:2, 406-20.

Hill, Kim Quaile, and Jan E. Leighley. 1992. The policy consequences of class bias in state electorates. American Journal of Political Science 36:2, 351-65.

Hill, Kim Quaile, Jan E. Leighley, and Angela HintonAndersson. 1995. Lower-class mobilization and policy linkage in the U.S. states. American Journal of Political Science 39:1, 75-86.

Jacobs, Lawrence R., and Robert Y. Shapiro. 2000. Politicians Don't Pander: Political Manipulation and the Loss of Democratic Responsiveness. Chicago: University of Chicago Press.

Lijphart, Arend. 1997. Unequal participation: Democracy's unresolved dilemma. American Political Science Review 91:1, 1-14.

Lippmann, Walter. 1925. The Phantom Public: A Sequel to "Public Opinion." New York: Macmillan.

Nie, Norman, Jane Junn, and Kenneth Stehlik-Barry. 1996. Education and Democratic Citizenship in America. Chicago: University of Chicago Press.

Nie, Norman, Sidney Verba, and John Petrocik. 1976. The Changing American Voter. Cambridge: Harvard University Press.

Petrocik, John. 1987. Voter turnout and electoral preferences: The anomalous Reagan elections. In Elections in America, ed. Kay Lehman Schlozman. New York: Allen and Unwin.

Piven, Frances Fox, and Richard A. Cloward. 1988. Why Americans Don't Vote. New York: Pantheon Books.

Rae, Douglas, Douglas Yates, Jennifer Hochschild, Joseph Morone, and Carol Fessler. 1981. Equalities. Cambridge: Harvard University Press. 
Rawls, John. 1972. A Theory of Justice. Cambridge: Belknap Press, Harvard University Press. . 1993. Political Liberalism. New York: Columbia University Press.

Rosenstone, Steven J., and John Mark Hansen. 1993. Mobilization, Participation, and Democracy in America. New York: Macmillan.

Schlozman, Kay Lehman. 2002. Political participation. In Political Science: The State of the Discipline, eds. Ira Katznelson and Helen Milner. Washington, D.C.: American Political Science Association.

Schlozman, Kay Lehman, and Sidney Verba. 1979. Injury to Insult: Unemployment, Class, and Political Response. Cambridge: Harvard University Press.

Schumpeter, Joseph. 1942. Capitalism, Socialism, and Democracy. New York: Harper and Brothers.

Sen, Amartya. 1999. Development as Freedom. New York: Alfred A. Knopf.

Shaffer, Stephen D. 1982. Policy differences between voters and non-voters in American elections. Western Political Quarterly 35:4, 496-510.

Stouffer, Samuel Andrew. 1955. Communism, Conformity, and Civil Liberties: A Cross-Section of the Nation Speaks Its Mind. Garden City, N.Y.: Doubleday.

Sullivan, John L., James Piereson, and George E. Marcus. 1982. Political Tolerance and American Democracy. Chicago: University of Chicago Press.

Teixeira, Ruy A. 1992. The Disappearing American Voter. Washington, D.C.: Brookings Institution Press.

Tilly, Charles. 1998. Durable Inequality. Berkeley: University of California Press.

Verba, Sidney. 2000. Representative Democracy and Democratic Citizens: Philosophical and Empirical Understandings. The Tanner Lectures on Human Values, delivered at the University of Oxford. Salt Lake City: University of Utah Press.

Verba, Sidney, Steven Kelman, Gary Orren, Ichiro Miyake, Joji Watanuki, Ikuo Kabashima, and G. Donald Ferree. 1987. Elites and the Idea of Equality: A Comparison of Japan, Sweden, and the United States. Cambridge: Harvard University Press.

Verba, Sidney, and Norman H. Nie. 1972. Participation in America: Political Democracy and Social Equality. New York: Harper and Row.

Verba, Sidney, Norman H. Nie, and Jae-on Kim. 1979. Participation and Political Equality: A Seven Nation Comparison. New York: Cambridge University Press.

Verba, Sidney, and Gary R. Orren. 1985. Equality in America: The View from the Top. Cambridge: Harvard University Press.

Verba, Sidney, Kay Lehman Schlozman, and Henry E. Brady. 1995. Voice and Equality: Civic Voluntarism in American Politics. Cambridge: Harvard University Press.

Verba, Sidney, Kay Lehman Schlozman, Henry E. Brady, and Norman H. Nie. 1990. American Citizen Participation Study. ICPSR version available at www.icpsr.umich.edu/ cgi/archive.prl?study=6635. Accessed 5 August 2003.
Verba, Sidney, Kay Lehman Schlozman, and Nancy Burns. 2003. Family ties: Understanding the intergenerational transmission of participation. Available at www.russellsage. org/programs/proj_reviews/si/wpschlozmanverba01.pdf. Accessed 12 September 2003.

Weaver, Vesla M. 2001. Racial profiling at the polling place: The impact of felony disenfranchisement on black political participation. Undergraduate thesis, University of Virginia.

Wilson, James Q., and Edward C. Banfield. 1964. Publicregardingness as a value premise in voting behavior. American Political Science Review 58:4, 876-87.

Wolfinger, Raymond E., and Steven J. Rosenstone. 1980. Who Votes? New Haven: Yale University Press.

Zaller, John R. 1992. The Nature and Origins of Mass Opinion. New York: Cambridge University Press.

\section{Notes}

1 Boswell and Tocqueville quotations, epigraphs from Verba and Orren 1985; Paris wall graffiti, epigraph from Verba and Nie 1972.

2 An earlier version of this article was read as the Johan Skytte Prize Lecture at the University of Uppsala, Sweden, in September 2002. I am grateful to the Johan Skytte Foundation and to Professor Leif Lewin for the opportunity to deliver the lecture.

This article draws on a long series of empirical works about political equality. Many of these studies have been conducted by me along with a number of collaborators. I have had the good fortune to have worked with, and to continue working with, some of the finest scholars in the discipline. This article is a product of that very fruitful collaboration. I refer to Gabriel Almond, with whom I started studying citizen engagement more than 40 years ago (and whose recent death has taken from us one of America's great social scientists); to Norman Nie, Jae-on Kim, John Petrocik, and Gary Orren, with whom I continued the work 20 to 30 years ago; and Kay Lehman Schlozman, Henry Brady, and Nancy Burns, with whom I have been pursuing the subject for the last two decades or so. The "I" absolves them of responsibility for judgments they may not share, since we did not go through the usual process of battling each sentence together, but not the credit for a large body of research on which the ideas in this article are based. The key relevant works are Almond and Verba 1963; Verba and Nie 1972; Nie et al. 1976; Verba et al. 1979; Schlozman and Verba 1979; Verba and Orren 1985; Verba et al. 1987; Verba et al. 1995; and Burns et al. 2001.

3 Note that equal consideration of needs and preferences does not and cannot mean equal treatment. Citizen needs and preferences are many and varied, and they often conflict. Public policies cannot satisfy all equally. Equal consideration just means that citizen voices are equally expressed and given an equal hearing, even if some receive a 
more beneficial response. Similarly, one person/one vote means that each citizen's vote is counted the same-even if some win and others lose.

4 Rae et al. 1981.

5 For a recent thorough summary of the literature on political participation, see Schlozman 2002.

6 For a discussion of the difference in how empirical researchers and political philosophers approach public opinion and political behavior, see Verba 2000.

7 The level of participation and the equality of participation are closely related. If everyone participated (voting turnout was 100 percent), there would be full equality across all relevant social groups. However, at the lower level of participation that is the case for voting turnout and even more so for other acts, gross inequality frequently occurs in the United States. From the perspective of representation through equal participation across politically relevant groups, a random sample surveyeven though only a very small number of the public (compared with the eligible electorate) would participate-might provide adequate representation. But a survey would give few a sense of membership, and it would not foster legitimacy. See Verba et al. 1995; Brehm 1993.

8 Verba and Nie 1972; Verba et al. 1995; Schlozman 2002.

9 This point needs qualification, however. Formal rights may exist but be violated in practice. Consider, for instance, the 2000 election in Florida, where there appears to have been differential opportunity to vote, depending on where one lived-with serious consequences for racial equality in opportunity to vote.

10 There are, of course, restrictions on campaign contributions by citizens, but these are not unequal across citizens-at least in terms of what is allowed if not in terms of what citizens can actually afford.

11 In 1998, 3.9 million people, or 2 percent of the population, had lost their right to vote because of felony voting disqualification statutes. Of all disenfranchised felons, black males constitute about 36 percent. In other words, 1.4 million black men, or 14 percent of all black males, cannot vote. Black men in the South are disenfranchised at even more disparate rates. In Alabama and Florida, 31 percent of black men are permanently barred from voting; in Virginia, Mississippi, New Mexico, Washington, and Tennessee, this number is one in four; and in Texas and Delaware, one in five. Weaver 2002.

12 Whether the restrictions on felons have a racial motivation is unclear. The fact that the states with the most restrictive rules in relation to voting by ex-felons include Alabama, Mississippi, Virginia, Florida, and Tennessee suggests that racial considerations may be important. On the other hand, Washington is on the list as well.

13 However, as the 2000 election in Florida demonstrated, despite well-established voting rights, casting a ballot was made more difficult for disadvantaged African Americans because of variations in voting technology and in the application of registration and voting regulations.

14 Sen 1999.

15 Recent work beginning to close this gap includes Hill, Leighley, and Hinton-Andersson 1995; Hill and Leighley 1992; and Bartels 2002. For an earlier attempt to link activity to government response, see Verba and Nie 1972, chapters 17-9.

16 See Verba, Schlozman, and Brady 1995 for more details.

17 Verba et al. 1995.

18 This distinction is not always clear-cut. Resources and motivation are not necessarily independent of each other; an individual who lacks the former may therefore have less of the latter.

19 Brady, Verba, and Schlozman 1999.

20 Direct democracy - whether writ large as referenda or writ small as participatory democracy in local governmentdoes exist with mixed success, but it is always within the framework of a representative system.

21 Dahl 1989; Rawls 1972.

22 In addition, citizens ought to have autonomous preferences, not preferences that are created by elite manipulation or "spin." See Zaller 1992; Jacobs and Shapiro 2000.

23 Rawls 1993.

24 Lippmann 1925; Schumpeter 1942.

25 The amount contributed is for the 1988 election year.

26 Verba, Schlozman, and Brady 1995; Nie, Junn, and Stehlig-Berry 1996. See also Stouffer 1955 and Sullivan et al. 1982. I don't want to overstate this case. There is the possibility that we give educated citizens more benefit of the doubt than they deserve when it comes to civic virtue. This may be because they speak our language. Some early research on the civic-mindedness of citizens found that better-educated citizens were more likely to have a long time horizon and to think of the public good when contemplating social and economic issues. Lesseducated citizens and newer immigrants had a shorter time horizon and thought of policies from the point of view of immediate impact on themselves (see Wilson and Banfield 1964). I think there is some truth to this, but many years of looking at what respondents say about public issues have also made clear that those who are more articulate have little difficulty expressing self-interest in broad social terms. In our research on unemployment, Schlozman and I found that less-educated people need a job and ask for a job. More-educated respondents need a job and discuss the problem of unemployment-while also asking for a job. See Schlozman and Verba 1979. When sending research proposals to the National Science Foundation, neither my colleagues nor I have ever argued that the research funding would allow us to do what we like better to do (research) rather than what we might otherwise have to do (teach), or that the funding would increase the prestige of our research institute. But it just may be that some of us have such things in mind-as well as having a sincere commitment to the substance of 
the research and its value to scholarship and the understanding of society.

27 Schumpeter 1942.

28 Wolfinger and Rosenstone 1980.

29 Verba, Schlozman, and Brady 1995. See also DeNardo 1980 and Shaffer 1982.

30 Bennett and Resnick 1990.

31 Teixeira 1992. Petrocik 1987, however, finds that it might have made a difference in 1980 and 1984. See also Hill and Leighley 1992.

32 See, for instance, Piven and Cloward 1988.

33 Verba et al. 1990.

34 The data are based on two standard seven-point-scale questions: one on government provision of jobs and the other on cutting social spending.

35 Respondents were asked a series of questions about financial strain they had faced in the previous year-inadequate funds for food, health care, housing, or recreation - and whether they had to work extra hours to make ends meet. The data are for those who reported no financial pinch across the various questions.

36 Aid for Families with Dependent Children, food stamps, or rent subsidies.

37 Sen 1999.
38 Verba, Schlozman, and Brady 1995; Burns, Schlozman, and Verba 2001.

39 The dependent variable is a scale based on several more or less standard questions about preferences for government policies to aid the unemployed or others needing social services.

40 In the Citizen Participation Study, respondents were asked about the issues that may have motivated their activity. A quite strikingly high proportion (56 percent of campaign workers, 87 percent of contactors and community activists, and 95 percent of protesters) said that there was such an issue and named it. For further details and a description of the questions asked, see Verba et al. 1995.

41 Tilly 1998.

42 Verba, Schlozman, and Burns 2003.

43 Verba, Nie, and Kim 1979.

44 Rosenstone and Hansen 1993.

45 This does not mean that the political preferences of affluent Republican and Democratic contributors are the same. The latter are more liberal than the former. But the stratification pattern in terms of actual economic position is clear.

46 Brady, Verba, and Schlozman 1999.

47 For an argument in favor of it, see Lijphart 1997. 